\title{
Observing Variations of Differences on COVID-19 in Varous Regions Extracting Type and Mutation Information
}

Jianzhong Liu

Yunnan University

Jeffrey Zheng ( $\sim$ conjugatelogic@yahoo.com )

Yunnan University

\section{Research Article}

Keywords: genome, COVID-19, base mutation, datum gene sequence, variation detection

Posted Date: January 8th, 2021

DOl: https://doi.org/10.21203/rs.3.rs-74632/v2

License: (c) (1) This work is licensed under a Creative Commons Attribution 4.0 International License.

Read Full License 


\title{
Observing Variations of Differences on COVID-19 in Varous Regions Extracting Type and Mutation Information
}

Jianzhong Liu, Jeffrey Zheng

\begin{abstract}
Covid-19 genomes were collected from three regions: Shanghai-China, Tbilisi-Georgia and Sydney-Australia. Five similar genomes were selected from each region for research in this paper. Applying the "datum gene sequence" method proposed, our results show that variation is immense in the Sydney-Australia region, followed by variation in the Tbilisi-Georgia region, which has a minimal value in the Shanghai-China region.

Keywords: genome, COVID-19, base mutation, datum gene sequence, variation detection
\end{abstract}

Jianzhong Liu

Key Laboratory for Software Engineering of Yunnan Province, Yunnan University, Kunming China e-mail: liujianz6655@qq.com

Jeffrey Zheng

Key Laboratory of Quantum Information of Yunnan

Key Laboratory of Software Engineering of Yunnan

School of Software, Yunnan University e-mail: conjugatelogic@yahoo.com

This work was supported by the NSFC (62041213), the Key Project on Electric Information and Next Generation IT Technology of Yunnan (2018ZI002),NSF of China(61362014),and Yunnan Advanced Overseas Scholar Project. 


\section{Introduction}

In Covid-19 research, the number of mutations and the types of mutations in the gene sequences are of great importance. It can roughly reflect the variation size and evolutionary direction of Covid-19 in a region. Base mutation analysis is likewise a common method in genes [1]-[7].

\section{Materials and Methods}

In Covid-19 gene sequences in the three regions of Shanghai-China, Tbilisi-Georgia and Sydney-Australia [8], we selected five similar gene sequences in each region for research.

We suppose that all five gene sequences have evolved from an original gene sequence (in this paper called the datum gene sequence).

For this reason, we first solve "datum gene sequence" using the filtering method. The method is as follows:

(1). Arrange by sequence number, align 5 gene sequences Seqi $(i=1,2,3,4,5)$;

(2). For sequence number $\mathrm{j}$, the corresponding values of the 5 gene sequences are Seqi $[j](i=1,2,3,4,5)$;

(3). Let the datum gene sequence DatumSeq[j] be equal to the most abundant value in Seqi $[\mathrm{j}](\mathrm{i}=1,2,3,4,5)$.

For example, if Seq1[j] =Seq2[j]=Seq3[j]=T, Seq4[j]=A, Seq5[j]=C, then DatumSeq[j] $=$ T.

\section{Results}

Based on the datum gene sequence, we identified the mutant bases of five gene sequences relative to the datum gene sequence. The number and type of base mutations were counted, and the work done is illustrated in the chart below.

\section{The Number and Type of Base Mutations in Five Covid-19 Gene} Sequences From Shanghai-China Region.

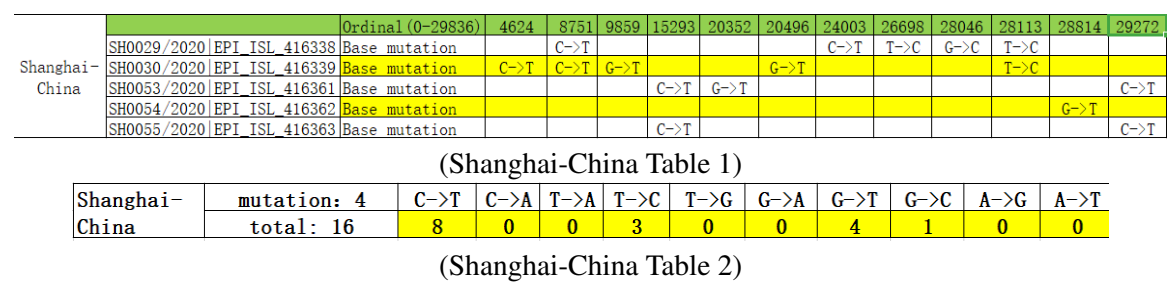




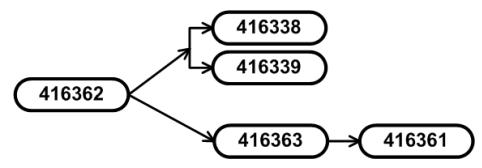

(Shanghai-China Figure 1)

The Number and Type of Base Mutations in Five Covid-19 Gene Sequences From Tbilisi-Georgia Region.

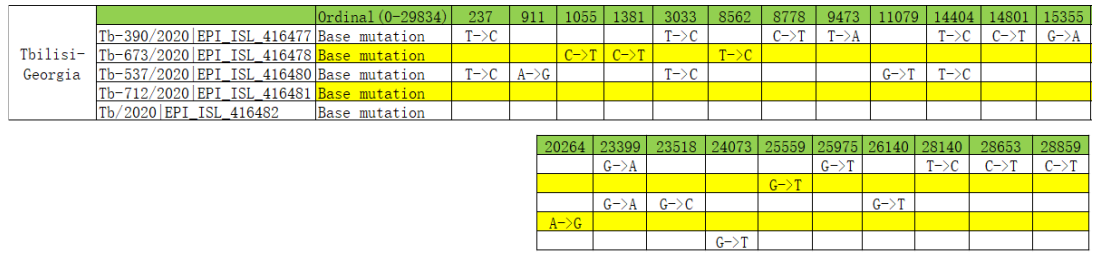

(Tbilisi-Georgia Table 1)

\begin{tabular}{l|c|c|c|c|c|c|c|c|c|c|c|}
\hline $\begin{array}{c}\text { Tbilisi- } \\
\text { Georgia }\end{array}$ & mutation: 7 & $\mathrm{C}->\mathrm{T}$ & $\mathrm{C}->\mathrm{A}$ & $\mathrm{T}->\mathrm{A}$ & $\mathrm{T}->\mathrm{C}$ & $\mathrm{T}->\mathrm{G}$ & $\mathrm{G}->\mathrm{A}$ & $\mathrm{G}->\mathrm{T}$ & $\mathrm{G}->\mathrm{C}$ & $\mathrm{A}->\mathrm{G}$ & $\mathrm{A}->\mathrm{T}$ \\
\cline { 2 - 11 } & total: 26 & 6 & 0 & 1 & 8 & 0 & 3 & 5 & 1 & 2 & 0 \\
\hline
\end{tabular}

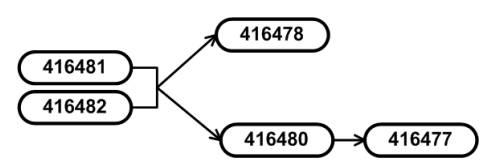

(Tbilisi-Georgia Figure 1)

The Number and Type of Base Mutations in Five Covid-19 Gene Sequences From Sydney-Australia Region.

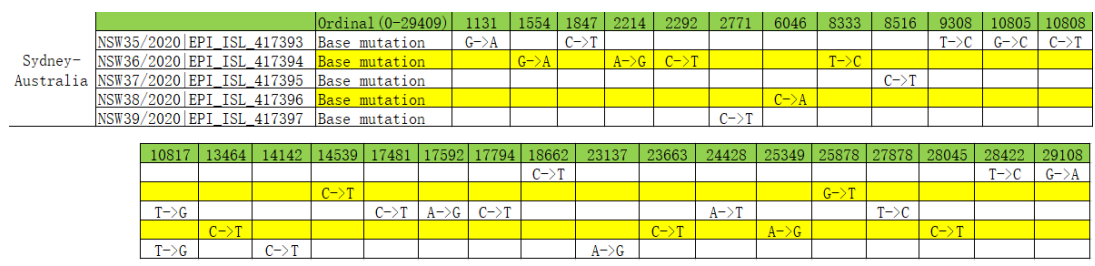

(Sydney-Australia Table 1) 


\begin{tabular}{l|c|c|c|c|c|c|c|c|c|c|c}
\hline $\begin{array}{l}\text { Australia } \\
\text { Sydney }\end{array}$ & mutation: 9 & $\mathrm{C}->\mathrm{T}$ & $\mathrm{C}->\mathrm{A}$ & $\mathrm{T}->\mathrm{A}$ & $\mathrm{T}->\mathrm{C}$ & $\mathrm{T}->\mathrm{G}$ & $\mathrm{G}->\mathrm{A}$ & $\mathrm{G}->\mathrm{T}$ & $\mathrm{G}->\mathrm{C}$ & $\mathrm{A}->\mathrm{G}$ & $\mathrm{A}->\mathrm{T}$ \\
\cline { 2 - 10 } & tota1: 30 & 13 & 1 & 0 & 4 & 2 & 3 & 1 & 1 & 4 & 1 \\
\hline
\end{tabular}

(Sydney-Australia Table 2)

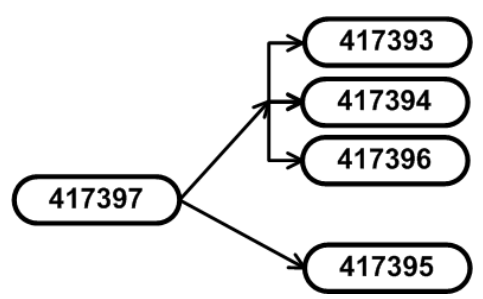

(Sydney-Australia Figure 1)

\section{Discussion}

Only from the analysis of our experimental data and experimental results:

(1). There are 4 variant base types and 16 mutation bases in the 5 gene sequences of the Shanghai-China region. Therefore, we can say that Covid-19 in the Shanghai-China region is pure, and the direction of Covid-19's evolution is clear (see Shanghai-China Figure 1).

(2). There are 9 variant base types and 30 mutation bases in the 5 gene sequences of the Sydney-Australia region. Therefore, we can say that the Covid-19 variation in the Sydney-Australia region is complex, and Covid-19 has many evolutionary directions(see Sydney-Australia Figure 1).

(3). There are 7 variant base types and 26 mutation bases in the 5 gene sequences of the Tbilisi-Georgia region.

\section{Conflict Interest}

No confilct of interest has claimed.

\section{References}

1. Ye X.D., and Zhang J.Y., 2018, Study on the single-base mutation in coding sequence of gene based on power spectrum analysis,(Genomics and Applied Biology), 38(2): 563-567.

2. ZHI Hao, MAO Yu-feng,MA Peng 2013,Algorithms for Recognizing Genes short coding sequence and genovariation Detection, (Mathematics in Practice and Theory),43(14):77-84.

3. XIE Ming-jie, ZHANG Lei,CAI Rong-rong,CHEN Xi,JI Xing-lai,2010,Feature analysis of the base mutations in coding region(BMCRs) of human syndrome-related genes, (Journal of Liaoning Normal University(Natural Science Edition)),33(2):223-227.

4. Liu Jianzhong,Theory of Inversion Set and Its Application, Yunnan Science and Technology Publishing Press,1999.刘建忠，反演集合理论及其应用，云南科技出版社 1999 . 
5. Jeffrey Zheng, Variant Construction from Theoretical Foundation to Applications, Springer Nature 2019 https://www.springer.com/in/book/9789811322815.

6. Jeffrey Zheng, Variant Construction Theory and Applications, Vol. 1: Theoretical Foundation and Applications, Science Press 2020 (Chinese, Formal Publishing Soon). 郑智捷, 变值体系 理论及其应用第 1 册: 理论基础及其应用, 科学出版社 2020 (即将正式发行)

7. Jeffrey Zheng,ResearchGate http://researchgate.net/pprofile/Jeffrey Zheng .

8. https://www.gisaid.org/ 
Figures
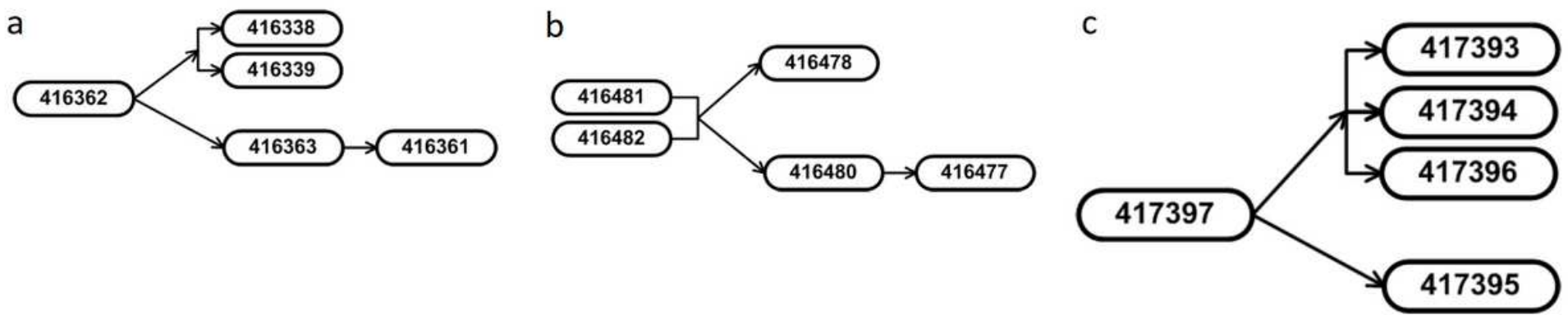

\section{Figure 1}

The Number and Type of Base Mutations in Five Covid-19 Gene Sequences From a. Shanghai-China Region b. Tbilisi-Georgia Region c. Sydney-Australia Region 